\title{
THE CREATION OF CLUSTERS OF VALUE TO REDUCE YOUTH UNEMPLOYMENT IN LITHUANIA AND SPAIN
}

\author{
Amaya ERRO-GARCÉS (D ${ }^{1 *}$, Giedrius ČYRAS (D ${ }^{2}$ \\ ${ }^{I}$ Department of Business Administration, Faculty of Economics and Business Administration, \\ Public University of Navarre, Campus Arrosadia s/n, 31006, Pamplona, Spain \\ ${ }^{2}$ Department of Business, Technologies, and Entrepreneurship, Faculty of Business Management, \\ Vilnius Gediminas Technical University, Sauletekio al. 11, 10223, Vilnius, Lithuania
}

\section{${ }^{*}$ E-mail: amaya.erro@unavarra.es}

\begin{abstract}
Purpose - this article presents empirical evidence of the creation of clusters of value that emerge when creativity, innovation, and entrepreneurship are developed together. These clusters contribute to welfare creation and, to the reduction of youth unemployment.

Research methodology - this paper aims to conduct an exploratory qualitative research study through multiple case studies.

Findings - findings show the relevance of emotions in social initiatives, the role of teams and experts that recognizes innovations, the relevance of stakeholders wealth to motivate employees and the importance of linking the day-to-day challenges to local apprenticeship programs, as creativity is closely related to these daily lives and everyday concerns.

Research limitations - this research paper has some limitations because multiple cases studies not allow for generalizations. An extension of this study encompassing a greater number of case studies could confirm findings.

Practical implications - this article describes the role of future entrepreneurs and can be applied in the identification of entrepreneurs' skills and characteristics.

Originality/Value - it is related to how to support entrepreneurs, taking into account the role of key actors, their teams, their local situation, and their intentions. Emotions were essential in the cases presented, and, even more, for the professionals that joined the initiatives.
\end{abstract}

Keywords: youth unemployment, clusters, creativity, multiple case study, digital professions.

JEL Classification: J0, J71, O35, I28.

Conference topic: Digitalization of Business Processes: Trends, Challenges, Solutions.

\section{Introduction}

Entrepreneurship can be defined as the discovery of opportunities and the subsequent creation of new economic activity, often via the creation of a new organization (Reynolds, 2005). Entrepreneurs do not just concerned about profits but also about the creation of new products and services, and, consequently, about the creation of employment and welfare. Along with this line, the stakeholders' theory states that a company must create value for all affected groups involved in the business (e.g., employees, customers, suppliers, financiers, communities, governmental actors, politicians, and trade unions). Because of that reason, the creation of a territory's welfare depends upon the competitiveness of its business and this closely linked to the competences of its entrepreneurs (Stevenson \& Jarillo, 2007).

Giving the relevance of entrepreneurs in a country's wealth, it is important to identify the motivations of entrepreneurs and the variables that can stimulate entrepreneurship. This is even more significant at a time when unemployment and, particularly, youth unemployment is one of the main problems in Europe. In this line, according to the European 2020 Strategy, the European Union's employment rate should achieve a 75 percent before 2020, which is an ambitious objective taking into account that the economic crisis has had effects on European unemployment, and especially, on youth unemployment (Scarpetta, Sonnet, \& Manfredi, 2010).

In this context, several projects (European Commission, 2019) have been designed to improve the employability of young people in Europe. To quote an example of these initiatives, the "Integral Qualification and Employment 
Programme" was defined by the Spanish Chambers of Commerce to facilitate advice and training to young people who have finished their Grades or become unemployed.

As it was mentioned, taking into account the challenge of youth unemployment in the European Union, the analysis of the entrepreneurs' motivations is an essential field of research. Previous research worked on the reasons that drive entrepreneurship (e.g., Stephan, Hart, Mickiewicz, \& Drews, 2015; Elfving, Brännback, \& Carsrud, 2017). Nevertheless, emotions and feelings were not included in most of this research or were not treated with enough relevance.

Precisely, this paper aims to fulfill this gap through the lessons learned by the analysis of successful entrepreneurs and their motivations. Specifically, the paper is focused on the role of creativity and emotions as drivers of entrepreneurship. In concrete, the purpose of this research is to answer the following questions:

- Are there lessons to learn from the successful experiences of entrepreneurs that created welfare in their countries?

- As European youth unemployment is a great challenge in the next years, is it possible to design entrepreneurship programs that respond to the present and future needs and create new jobs in Europe?

- May there be some relationship between emotions and these programs' success?

It should be noted that these questions address a very important field of research in entrepreneurship and European youth employment policy. In fact, a new perspective is deemed necessary in order to gain a thorough understanding of how to create successful valued services for Youth in Europe.

\section{Theoretical background: creativity, emotions, and stakeholders}

Previous research on the motivations of entrepreneurs, and, particularly, the role of emotions and creativity in entrepreneurship were studied. In order to structure the theoretical background in this field, three topics are considered: the role of emotions and feelings in management, the stakeholder theory, creativity and creativity, emotions and stakeholders. The next subsections explore this literature.

\subsection{Emotions and feelings in management}

Considering the role of emotions and feelings in management is not a new issue. Just a search of the term "emotional management" reflects a total of 3,200,000 results in Google Scholar.

Since Goleman (2004) incorporated emotional intelligence in management, emotions have been considered in the organizational theory to explain managers' behavior. It is widely assumed that working for companies that have a wider purpose than just the maximization of shareholder wealth is more motivating than just looking for the business's benefits.

Ashkanasy, Humphrey, and Huy (2017) summarized organizational research that included emotions in management theory. They referred to several new works on emotions and management. To quote some of them, they described the study of Lebel (2017) on negative emotions, the article from Oh and Farh (2017) on an emotional process theory of how subordinates respond to abusive supervision over time, the model of Cropanzano, Dasborough, and Weiss (2017) of the three stages of LMX relationship development (role taking, role making, role routinization) using effective events theory, or the study Rothman and Melwani (2017) of the social functions of emotional complexity for leaders.

Spreitzer and Sonenshein (2004) developed a theoretical framework to explain how workers participate in positive behaviors in companies. Along with this line, they showed some possible positive outcomes of emotions in management, such as subjective well-being, long-term effectiveness, and the evolution of organizational and common business norms.

In fact, the role of emotions and feelings in management appears as a fruitful field of research and, consequently, several articles have been published on this issue in the last few years. The next subsection considers the stakeholder theory as all groups involved in a company are relevant in order to understand the objectives of a business project and, therefore, are essential to explain the motivations of entrepreneurs.

\subsection{Stakeholder theory}

The stakeholder theory is introduced as a theoretical background to explain the influence of the socio-political environment on entrepreneurs' objectives. According to the stakeholder theorists, demands from all groups involved in a company should be considered. As a result, a new socio-political level appears in the analysis of a firm's strategy. Although the Stakeholder Theory is not a new approach, in recent years, several scholars contributed to the field by reinforcing a model of corporate behavior (Jensen, 2017) or by analyzing the stakeholder theory under the perspective of business ethics (Jones, Wicks, \& Freeman, 2017).

In the analysis of drivers of entrepreneurs, Côté and Miner (2006) identified an innovative assumption in the field of stakeholder theory research that involves the emotional dimension. As their paper affirms, there is evidence, in the context of the stakeholder theory, that emotions affect managers, and, consequently, positive emotions are emerging as a specific area in the organizational theory. Precisely, this research paper tries to contribute to this field, by the 
development of this emerging area of research, presenting six longitudinal case-studies, in response to the request of Laplume, Sonpar, and Litz (2008) to consider that there was enough conceptual activity in previous research on emotions under the stakeholder theory's perspective ( $\mathrm{n}=50$ from 179 papers studied in Freeman's article) but very few empirical research $(n=5)$ in this field.

Finally, the social and emotional value created to stakeholders was considered by Retolaza, San-Jose, and RuizRoqueñi (2014). They identified a model were these perspectives were included and all stakeholders were added in the model to measure the creation of value.

\subsection{Creativity, emotions and stakeholders}

Csikszentmihalyi (2014) pointed out the relevance of outsiders to explain creativity. He explained that creativity comes from several interactions between culture, the innovative person and a group of experts that work on the recognition and validation of the innovation. Moreover, Csikszentmihalyi (2014) affirms that creative problems usually emerge from areas of life that are important from a personal perspective.

With regard to the management of creative people, Berg, Grimstad, Škerlavaj, and Černe (2017) add the relational aspect of leadership for stimulating employee creative behavior. Along with this line, Munro (2017) focuses on organizations and advocates reconfiguring them to create authentic open spaces that stimulate creativity and imagination. In addition, Koch, Wenzel, Senf, and Maiber (2017) also conceive creativity in a framework of constant negotiation with the surroundings, whereas Barkey and Godart (2017) consider that the form of governance affects creative behavior. In summary, creativity and its management have been considered in the field of human resources management, as creative people are needed to create value in companies. For the same reasons, creativity is relevant as an entrepreneur skill.

Once the role of emotions and feelings in management is addressed and the importance of creativity is described, this subsection aims to explore the relationship between creativity, emotions, and stakeholders in the creation of value. From previous findings, the close relationship between entrepreneurship, creativity, innovation, and emotions was described by De Val and Erro (2017). Their research quoted creativity as a cognitive and volitional ability linked to the emotional system. Under this conception, creativity is embedded by emotions.

Considered the effects of creativity on business and the firm's environment, De Val and Erro (2017) stated that "when creativity, innovation, and entrepreneurship are developed together, a cluster of value appears -as several value chains are bundled together-, and social welfare emerges". In other words, the creation of a cluster of value which results from creative innovations and that is developed as a new project by entrepreneurs results in several new activities that generate value to different collectives.

Precisely, this research aims to present empirical evidence of the described relationship between creativity, emotions, and entrepreneurship. Even more, this article shows how a cluster of value is created when all these behaviors are developed together. To sum up, the Stakeholder Theory provides a theoretical framework to employ for the research questions proposed above. The role of creativity and emotions as drivers of value, and, in fact, social welfare will focus our efforts in order to provide helpful answers to the research questions detailed.

\section{Methodology and data}

In seeking to achieve the formulated research questions, a general qualitative analysis is proposed (Yin, 1984, 2001; Eisenhardt \& Graebner, 2007). Multiple case-studies are analyzed to present empirical evidence of the mentioned role of creativity and emotions to create value in entrepreneurship projects. Although this methodology might present some limitations in the generalization of results, several authors justify its application (Miles, Huberman, \& Saldana, 2014; Galuk, Zen, Bittencourt, Mattos, \& Menezes, 2016). Qualitative analysis facilitates a holistic perspective to complex situations and, moreover, helps to address contextual conditions in conducting research of inductive nature, as is the case of the studies presented (Eisenhardt, 1989; Eisenhardt \& Graebner, 2007; Gummesson, 2000).

The number of successful experiences located in Spain and Lithuania is presented in this exploratory qualitative research study. In all case studies, the main character is a person who started a business searching for unemployment reduction and looking social welfare. Information was collected from different sources, in order to support and triangulate the findings (Jick, 1979). For each experience, the case is described and the main outcomes are identified (Table 1).

\section{Discussion}

This research paper aims to analyze several case-studies to study the motivations of the entrepreneurs to start their projects that helped several citizens in each territory. 
Table 1. Case-studies description

\begin{tabular}{|c|c|c|c|}
\hline Country & Year & Success case & Outcome \\
\hline Lithuania & 2015 & $\begin{array}{l}\text { The case of an online marketplace of second-hand } \\
\text { clothes Vinted, one of Lithuania's star start-ups } \\
\text { did change a wave of online second-hand fashion } \\
\text { portals, which had hatched worldwide allowing its } \\
\text { users to sell abandon clothing. Poshmark, Thredup } \\
\text { and Twice from the US; Videdressing and Ves- } \\
\text { tiaire collective from France; Mädchenflohmarkt, } \\
\text { Stuffle and Rebelle and eBay. The company that } \\
\text { has been expanding its footprint worldwide - } \\
\text { Vinted, the start-up offering an online marketplace } \\
\text { letting its users sell, buy and exchange second- } \\
\text { hand clothing. }\end{array}$ & $\begin{array}{l}\text { The mobile-based application counts more than } \\
350 \text { magazines around the world, while its digital } \\
\text { business gives it access to some } 165 \text { million users. } \\
\text { Headquartered in Vilnius, Lithuania, the company } \\
\text { also has offices in San Francisco, Munich, Paris, } \\
\text { Warsaw, and Prague. } 2014 \text { Vinted has raised } \$ 27 \\
\text { million in Series C funding in a round led by inter- } \\
\text { national media company Hubert Burda Media. VC } \\
\text { firms Accel Partners and Insight Venture Partners } \\
\text { also participated in the round, which brings Vint- } \\
\text { ed's total of capital raised to just north of } \$ 60 \text { mil- } \\
\text { lion. }\end{array}$ \\
\hline $\begin{array}{l}\text { Lithuania/ } \\
\text { Spain }\end{array}$ & 2013 & $\begin{array}{l}\text { Based in Lithuania children app publisher } \\
\text { TutoTOONS, it has reached more than } 110 \text { mil- } \\
\text { lion game downloads (of its } 220+\text { games) in less } \\
\text { than } 3 \text { years after its start. With offices in Lithua- } \\
\text { nia and Spain, TutoTOONS has raised zero invest- } \\
\text { ment in funding from investors. Played by more } \\
\text { than } 1.5 \text { million children daily, TutoTOONS } \\
\text { games took a different approach in children educa- } \\
\text { tion and combine girls' favorite's casual games } \\
\text { like characters makeovers with the learning of } \\
\text { self-expression, personal care, good daily habit. }\end{array}$ & $\begin{array}{l}\text { The company releases about } 8 \text { new games every } \\
\text { month, but it also provides thousands of third par- } \\
\text { ties (artists and other creatives) with its game } \\
\text { building platforms. In } 2018350 \text { games were pub- } \\
\text { lished on the app stores and it had } 8.7 \text { million ac- } \\
\text { tive players. }\end{array}$ \\
\hline Lithuania & 2013 & $\begin{array}{l}\text { The company flagship product, the Deeper Sonar, } \\
\text { was launched in 2013, creating an entirely new } \\
\text { product category in the angling sector. It put de- } \\
\text { tailed sonar data into the hands of shore anglers for } \\
\text { the first time ever, by pairing the castable sonar } \\
\text { device with the user's smartphone. Since then, } \\
\text { Deeper has added four new spec models and four } \\
\text { accessories to its product portfolio. }\end{array}$ & $\begin{array}{l}\text { Developed, manufactured and designed in Lithua- } \\
\text { nia, this product line is sold now in over } 60 \text { mar- } \\
\text { kets globally and has picked up } 15 \text { international } \\
\text { awards. Most importantly, in } 2016 \text { Deeper Sonars } \\
\text { did win an Innovation Award at the Consumer } \\
\text { Electronics Show, with other winners that year in- } \\
\text { cluding Samsung, Lenovo, and HP. }\end{array}$ \\
\hline Spain & 1955 & $\begin{array}{l}\text { The Mondragon Corporation is an international } \\
\text { federation of worker cooperatives. The main suc- } \\
\text { cess of Mondragon Corporation was its ability to } \\
\text { create a sense of identity among the workers } \\
\text { within the company, encouraging an environment } \\
\text { of solidarity and collegiality among them, a feel- } \\
\text { ing that also extended to non-worker-owners. }\end{array}$ & $\begin{array}{l}\text { The company employs more than } 74,000 \text { people } \\
\text { all over the world and generates almost } 12 \text { billion } \\
\text { euros in annual sales. It works in several activities } \\
\text { such as the automotive sector, the food industry, } \\
\text { the household appliances sector... It created also a } \\
\text { bank to finance the growth of their activities. The } \\
\text { company operates internationally. }\end{array}$ \\
\hline Spain & 1931 & $\begin{array}{l}\text { Originating from a company called Imenasa, } \\
\text { Huarte Group was formed by several companies } \\
\text { such as Perfrisa, associated with the Altos Hornos } \\
\text { de Vizcaya, Baskonia, British group Lucas, Miasa } \\
\text { or Inasa. The group was also introduced in other } \\
\text { sectors such as paper and packing, foreign trade or } \\
\text { power through viticulture. }\end{array}$ & $\begin{array}{l}\text { Huarte Group was identified with innovation, as } \\
\text { all the companies in the group started new projects } \\
\text { in their time. To quote an example, it built a build- } \\
\text { ing in Madrid from the top to the ceiling, with an } \\
\text { innovative construction technique. Another com- } \\
\text { pany of the group, Inasa, together with American } \\
\text { Mark Reynolds, began the transformation of alu- } \\
\text { minum in Spain. The group strategy was to partner } \\
\text { with the best companies in each sector by central- } \\
\text { izing them in their homeland. }\end{array}$ \\
\hline Spain & 1994 & $\begin{array}{l}\text { "Peridis" is a Spanish architect who works in sev- } \\
\text { eral projects related to unemployed and helped } \\
\text { more than } 750,000 \text { unemployed people in the } \\
\text { world. Foundation Santa María la Real is his } \\
\text { main project. It fosters a program of career } \\
\text { launches and a solidarity campaign for the unem- } \\
\text { ployed. }\end{array}$ & $\begin{array}{l}\text { Designed to make up for the shortcoming of gov- } \\
\text { ernmental employment policies, where the unem- } \\
\text { ployed are passive and isolated, the programs from } \\
\text { Foundation Santa María la Real follow a holistic } \\
\text { approach that fosters the pro-activeness of individ- } \\
\text { uals, raises their skills and increases their visibil- } \\
\text { ity. It adopts a collaborative, supportive model, } \\
\text { based on people and their capacity for teamwork. } \\
\text { Participants in the schemes organize their activi- } \\
\text { ties for an average of } 6 \text { months and are led by a } \\
\text { coach. }\end{array}$ \\
\hline
\end{tabular}




\subsection{Motivations}

Three Lithuanian case studies as showed in Table 2 did face struggling's in the capital appeals stage due to the information dissymmetry's between founders and potential investors, which is most tangible in the period of concept building and product or technology development in specialized areas, particularly where investors might not possess the necessary expertise. Although in comparison with another Lithuanian newly opened companies, all these three appear to be more successful in capital attraction than others, which hints at the existence of certain factors, attributed to organizational or financial aspects, which seem to be shared by start-up companies and founders that manage to receive investors trust and seed capital. Vinted attracted investors with an idea to change the type of existed secondhand fashion portals; TutoToons enticed bondholders with an aim to understand how games can stimulate imagination and creativity of the children; deeper captivated depositors with achievement to combine simple angling with modern IT solutions.

Mondragon Corporation was created by father José María Arizmendiarrieta Madariaga. He was a Catholic priest in Arrasate, a village located in Mondragon. As he found a town suffering severe unemployment as a consequence of the Civil War, he started a polytechnic school, and, supported by students of the school, small businesses that will develop the Mondragon Corporation.

Table 2. Youth unemployment rate (source: Data from the OTT World Employment and Social Outlook, 2016)

\begin{tabular}{|c|c|c|c|c|}
\hline Country & LAST & & PREVIOUS & RANGE IN \% \\
\hline Kosovo & 56.00 & $09 / 2018$ & 55.1 & 61.01: 50.6 \\
\hline Greece & 38.50 & $10 / 2018$ & 36.7 & $60.2: 21$ \\
\hline Spain & 34.20 & $11 / 2018$ & 34.7 & $55.8: 17.1$ \\
\hline Italy & 31.70 & $11 / 2018$ & 32.3 & $43.2: 19.3$ \\
\hline Serbia & 25.20 & $09 / 2018$ & 27.6 & $54.2: 25.3$ \\
\hline Croatia & 23.90 & $09 / 2018$ & 23.8 & $49.8: 23.3$ \\
\hline France & 22.70 & $11 / 2018$ & 21.7 & $26.1: 14.4$ \\
\hline Portugal & 18.90 & $11 / 2018$ & 20.9 & 41.2: 11.2 \\
\hline Cyprus & 18.90 & $09 / 2018$ & 19.4 & $40.5: 7.9$ \\
\hline Finland & 16.90 & $11 / 2018$ & 17.8 & $35.8: 8.4$ \\
\hline Sweden & 16.90 & $11 / 2018$ & 17.1 & $27.7: 2.8$ \\
\hline Estonia & 17.10 & $10 / 2018$ & 18.2 & $40.5: 6.6$ \\
\hline Romania & 15.90 & $09 / 2018$ & 16.1 & $26.2: 15.4$ \\
\hline Belgium & 15.75 & $09 / 2018$ & 15.6 & $25.9: 13.9$ \\
\hline EU & 15.15 & $11 / 2018$ & 15.2 & 23.9: 15.2 \\
\hline Bulgaria & 14.15 & $11 / 2018$ & 13.7 & $38.5: 10.4$ \\
\hline Slovakia & 13.85 & $11 / 2018$ & 14.2 & 39.8: 13.8 \\
\hline Luxembourg & 12.35 & $11 / 2018$ & 12.7 & $22.6: 2.6$ \\
\hline Poland & 12.25 & $11 / 2018$ & 12.6 & 44.1: 11.2 \\
\hline Ireland & 12.15 & $12 / 2018$ & 12.2 & $31.5: 6.1$ \\
\hline United Kingdom & 11.35 & $09 / 2018$ & 11.1 & $22.2: 9.6$ \\
\hline Lithuania & 10.55 & $11 / 2018$ & 10.7 & $36.1: 7.5$ \\
\hline Latvia & 10.45 & $11 / 2018$ & 10.4 & $40.6: 7.6$ \\
\hline Hungary & 10.25 & $10 / 2018$ & 9.8 & 29.3: 9.3 \\
\hline Slovenia & 10.25 & $09 / 2018$ & 10.2 & $25.5: 8.8$ \\
\hline Austria & 8.75 & $11 / 2018$ & 9.4 & $13.2: 4.9$ \\
\hline Denmark & 8.35 & $11 / 2018$ & 8.5 & $17.3: 5.3$ \\
\hline Netherlands & 6.85 & $11 / 2018$ & 7.3 & 17.6: 6.5 \\
\hline Germany & 6.05 & $11 / 2018$ & 6.2 & 15.8: 5.6 \\
\hline Moldova & 5.95 & $09 / 2018$ & 7.9 & $36.9: 5.9$ \\
\hline Czech Republic & 4.85 & $11 / 2018$ & 5.2 & 21.7: 4.8 \\
\hline Switzerland & 2.35 & $12 / 2018$ & 2.5 & $5.6: 1.3$ \\
\hline
\end{tabular}


Félix Huarte became unemployed working for a company. As a consequence, he felt he should not depend on others to ensure his professional career and to provide economic resources for his family. With this idea in mind, he started the first companies of the Huarte Group. Finally, José María Pérez, (hereafter, Peridis), transformed his interest in the Romanic in a Project to help unemployed people. In fact, all main characters were driven by a non-profit reason to start their projects. Emotions and feelings were important in these decisions, as they did not just look for benefits.

\subsection{Process}

From all three selected Lithuanian start-up perspectives, the teams were teeming with young, ambitious professionals. They did choose Lithuania as a low-cost location to get started in. They all did use Startup Lithuania as a good resource as well as TechStars Startup Digest Lithuania, and Vilnius Tech Park, who was also fostering a community of startups, investors and accelerators. Factors influencing on success rate by Vinted were fortunate \& open-mind, which they did need it at all stages - preparation, submission, implementation. TutoTOONS were thoroughly following requirements of the Call, which led to ideology - if you do not understand the call ask your colleague or project office in your institution. The deeper idea was based on a quality of involved researchers proposed research, specialists in the fields which pursue state-of-art research. Their implementation impact could be described as a combination of science and management, which encompass sales and trading infrastructure, coordinator, project manager, financial manager. Quality of involved institutions in all three case studies was the leading role of coordination to make a realistic project consortium or groups. Key events in all success stories were presented at Startup Digest, and regular events include Silicon Vikings Vilnius, GDG Vilnius, BarCamp Vilnius, and the Open Coffee Club.

Both father José María Arizmendiarrieta and Félix Huarte worked with excellent professionals to create their companies. As it is showed in Table 2, Huarte's strategy was to partner with the best companies in each sector by centralizing them in their homeland. This strategy helped him to introduce innovative techniques and products in his companies.

Peridis aimed to involve most actors of the society (municipalities and governmental institutions, private local firms, NGOs, individual volunteers, local training centers, co-working or entrepreneurship centers, universities, etc.) into shaping a global solution to unemployment. As a result, he worked with several people and institutions to solve problems.

\subsection{Creativity}

Information technology (IT) is considered the most important factor in globalization and technological progress, the basis of knowledge association. Today's IT industry is and remains one of the fastest growing companies in the world. According to the Lithuanian Bureau of Statistics, IT believes that IT is one of the country's leading sectors that match the growth in benefits. The added value of the IT sector is increasing from year to year, which is about $3 \%$ of gross value added. The overall growth in IT production is and remains mainly due to the result of newly established information and communication technology equipment manufacturing companies. It should be noted that Lithuania has not weakened the overall contribution of the IT sector to the country's economic growth potential, which has motivated the search for new, unfulfilled areas in order to identify the areas of neighboring countries of Lithuania and find ways to compete in the global arena Create IT market.

According to statistics from the public company "Versli Lietuva", Lithuania has created a remarkable startup ecosystem over the last 6 years, consisting of over 400 startup companies. Small IT startup companies start popular IT products (for example Vinted, Deeper, TutoToons). Inspired by the largest IT corporations like Apple, Microsoft, success stories, young entrepreneurs generate ideas and develop innovative products while looking for opportunities to become leading companies. Some of the IT startup companies develop and grow into large, unaccompanied operating businesses. Others fail to overcome the competition and have to retreat (Tunčikienè \& Sinkevičiūtė, 2017).

Obviously, the external and internal environmental factors lead to the development and destiny of IT startup companies. Lithuania is rapidly moving in the path of modern electronic economic development. One of the country's most important economic activities - is striving to become a high-tech leader in the Baltic region.

According to M. Mason's calculations (Mason, 2017), about 137,000 new companies are registered every day worldwide. Entrepreneurial activity is on the rise and startups are popping up at an increased pace. However, only $0.25-2 \%$ of all US startup companies seeking venture capital receive financing (Rose, 2012). Thus, attracting capital is vital for a young innovative company's survival in the early stages and remains critical for its further expansion in later development stages.

In fact, in the Lithuanian cases, IT fostered creativity, as all the IT products were new products in the market. But, even more, in all cases, it can be concluded that these entrepreneurs introduced innovative solutions in their projects. Consequently, creativity appears as an essential characteristic of all these successful initiatives. 


\section{Findings and conclusions}

Lithuania showed the biggest improvement of all EU and OECD countries in 2018, mainly due to the reduction of redundancy costs. Lithuania outperformed Estonia in the 28th place and Latvia in the 20th. Along the same line, Spain modified its employment regulation and increases its competitiveness. Research shows that the attractiveness of a country's business environment and the degree of employment flexibility do not necessarily match. Lithuania is among the top ten EU and OECD countries in terms of business competitiveness, while it is ranked 15th by employment flexibility. The labor reform was an important step forward but the Labour Code is not flexible enough to reflect the needs of the 21st century and as liberal as the reform opponents claim it to be. Spanish situation is quite similar in competitiveness positions as Spain is located in the 26th place in the World Economic Forum index (2018) whereas it is not in employment flexibility, where Spain is in the 25th place. In order to improve the global situation, entrepreneurs' behavior is essential as they contribute to the creation of wealth in each country.

Along with this line, although youth unemployment is an important challenge in most European countries, some countries such as Spain present worse data. 34 percent of youths in Spain aged between 16 and 29 are unemployed (Active Population Survey, 2018). Meanwhile, in Lithuania, the youth unemployment rate remained at a lower percentage of 10.60 in October of 2018. Unemployment Rate of youth in Lithuania averaged 21.43 percent from 1998 until 2018, reaching an all-time high of 36.20 percent in February of 2010 and a record low of 7.60 percent in June of 2007 (Lithuanian Department of Statistics). On the other hand, as is shown in Table 2, the youth unemployment rate in Europe remains at $20.6 \%$. For that reason, and given the local versus global perspective of unemployment, this research is focused on Spanish and Lithuanian initiatives.

This paper aims to identify entrepreneurship drivers to enforce the creation of new companies and shows how welfare emerges when creativity, innovation, and entrepreneurship are developed together since a "cluster of value" appears. These clusters of value contribute not just to welfare creation but also to the reduction of youth unemployment, which is one of the main challenges of the countries considered. From successful experiences from the past, several lessons are obtained. In fact, this paper draws implications that this empirical evidence offers for the development of entrepreneurship. By doing so, Lithuanian and Spanish case-studies were analyzed as successful experiences that reduce unemployment and create welfare. As contributions, this article offers a reflection on several findings.

Firstly, the role of emotions as a key variable to entrepreneurship and employment creation is confirmed. All the cases investigated showed the effects of emotions in the development of successful initiatives that finally reduced unemployment. In the cases analyzed, the main character was moved by a non-profit motivation that was related to areas of life important for him or her (Csikszentmihalyi, 2014).

Messrs. Pérez, Arizmendiarrieta and Huarte were in search of a change in their cities or regions as they sook to solve a problem they identified in those territories. In this sense, their objectives could be described as the creation of new employs which could help citizens of those cities. By doing so, they developed clusters of value. Attitudes such as persistence, resilience, and values were essential for them to success. But, furthermore, they let themselves be ruled by the heart.

Secondly, the relevance of daily challenges to explain entrepreneurs' motivation was found in all cases. To quote an example, Mr. Arizmendiarrieta was concerned about the situation of youth with regard to unemployment; Mr. Huarte aimed to achieve a higher economic and social development of his region; Mr. Pérez focused on Aguilar de Campoo problems; Vinted was the only idea about creating a website where people could trade their pre-loved fashion with each other; TutoToons aimed to understand how games can stimulate the imagination and creativity of the children, build better habits, help to understand rules, socialize and become a team member; deeper aim was to combine simple angling with modern IT solutions.

In fact, the close relationship between the main characters and their local challenges was crucial to find sustainable and successful solutions. Moreover, this relation was essential for the business to succeed, as the new project was based on real problems and helped to solve them. In addition, creativity and emotions should be taken into account to solve these local challenges, and, consequently, the mentioned relation between creativity, emotions, and entrepreneurship is confirmed by this empirical evidences. Thirdly, the role of teams was also considered in all the business projects. Being surrounded by the best professionals and work in teams characterized most of the investigated cases. Mondragon Group, Huarte Group, Public Industrial Development Plan (PPI), Vinted, Tutotoons, and Deeper were supported by professionals that combined these main characters. They shared their values and projects, and this field of experts recognized innovations.

The existence of a superior objective related to wealth creation was relevant as a driver in all cases investigated to make further efforts to obtain social and economic development in each territory. Because of this situation, stakeholders were considered by all the entrepreneurs as they search the benefits of citizens and territories. Successful entrepreneurs looked for community wealth and not just for their own profits.

To sum up, the main findings from this article present suggestions about how to support youth unemployment, taking into account the role of the key actors, their teams, their local situation, and their intentions for developing those initiatives. Emotions were essential in the cases presented. Like all studies, this research paper has some methodological limitations because the multiple case study was conducted with three specific experiences, not allowing for generalizations. Nevertheless, we hope to contribute to the research on the topic and to the general debate around social 
work studies. An extension of this study encompassing a greater number of case studies could be done, in order to confirm findings.

According to Morrison (2006), “understanding and handling one's own and others' emotions is a critical aspect at every stage of the social work task. It is also an essential skill for managers. Emotional intelligence or competence is also pivotal to gaining the cooperation of other colleagues and services on which social workers depend. But the place of relationships and emotion in social work is in danger of becoming increasingly marginalized". This is precisely the reason why this research paper was conducted.

\section{Disclosure statement}

This work was supported by the from Ministerio de Economía, Industria y Competitividad and Fondo Europeo de Desarrollo Regional (FEDER) under Grant ECO2017-86305-C4-4-R.

\section{References}

Ashkanasy, N. M., Humphrey, R. H., \& Huy, Q. N. (2017). Integrating emotions and affect in theories of management. Academy of Management Review, 42(2). https://doi.org/10.5465/amr.2016.0474

Barkey, K., \& Godart, F. C. (2017). Empires, federated arrangements, and kingdoms: Using political models of governance to understand firms' creative performance. Organization Studies, 34(1), 79-104. https://doi.org/10.1177\%2F0170840612464754

Berg, S. T. S., Grimstad, A., Škerlavaj, M., \& Černe, M. (2017). Social and economic leader-member exchange and employee creative behavior: The role of employee willingness to take risks and emotional carrying capacity. European Management Journal, 35(5), 676-687. https://doi.org/10.1016/j.emj.2017.08.002

Côté, S., \& Miner, T. H. M. (2006). Emotional intelligence, cognitive intelligence, and job performance. Administrative Science Quarterly, 51(1), 1-28. https://doi.org/10.2189/asqu.51.1.1

Cropanzano, R., Dasborough, M. T., \& Weiss, H. M. (2017). Affective events and the development of leader-member exchange. Academy of Management Review, 42, 233-258. https://doi.org/10.5465/amr.2014.0384

Csikszentmihalyi, M. (2014). Society, culture, and person: A systems view of creativity. In M. Csikszentmihalyi, The Systems Model of Creativity (pp. 47-61). Netherlands: Springer. https://doi.org/10.1007/978-94-017-9085-7

De Val, I., \& Erro, A. (2017). Creatividad y Emprendimiento. Capacidad y Realidad. Comisión de Organización y Sistemas. AECA.

Eisenhardt, K. M. (1989). Building theories from case study research. Academy of Management Review, 14(4), 532-550. https://doi.org/10.5465/amr.1989.4308385

Eisenhardt, K. M., \& Graebner, M. E. (2007). Theory building from cases: Opportunities and challenges. Academy of Management Journal, 50(1), 25-32. https://www.jstor.org/stable/20159839

Elfving, J., Brännback, M., \& Carsrud, A. (2017). Motivations matter in entrepreneurial behavior: depends on the context. In M. Brännback \& A. Carsrud (Eds.), Revisiting the Entrepreneurial Mind (pp. 211-217). Cham: Springer. https://doi.org/10.1007/978-3-319-45544-0_14

European Commission. (2019). Employment, social affairs and inclusion. Youth employment. Retrieved from http://ec.europa.eu/social/main.jsp?catId=1036

Galuk, M. B., Zen, A. C., Bittencourt, B. A., Mattos, G., \& Menezes, D. C. D. (2016). Innovation in creative economy microenterprises: a multiple case study. RAM. Revista de Administração Mackenzie, 17(5), 166-187. http://dx.doi.org/10.1590/1678-69712016/administracao.v17n5p166-187

Goleman, D. (2004). What makes a leader?. Harvard Business Review, 82(1), 82-91.

Gummesson, E. (2000). Qualitative methods in management research. London: Sage.

Jensen, M. C. (2017). Value maximisation, stakeholder theory and the corporate objective function. In Unfolding stakeholder thinking (pp. 65-84). London and New York: Routledge. https://doi.org/10.4324/9781351281881-4

Jick, T. D. (1979). Mixing qualitative and quantitative methods: Triangulation in action. Administrative science quarterly, 24(4), 602-611. https://doi.org/10.2307/2392366

Jones, T. M., Wicks, A. C., \& Freeman, R. E. (2017). Stakeholder theory: The state of the art. The Blackwell guide to business ethics (pp. 17-37). Cambridge: Cambridge University Press.

Koch, J., Wenzel, M., Senf, N. N., \& Maibier, C. (2017). Attributional process: The case of haute cuisine. Organization Studies, 39(2-3), 251-270. https://doi.org/10.1177\%2F0170840617727779

Laplume, A. O., Sonpar, K., \& Litz, R. A. (2008). Stakeholder theory: Reviewing a theory that moves us. Journal of management, 34(6), 1152-1189. https://doi.org/10.1177/0149206308324322

Lebel, R. D. (2017). Moving beyond fight and flight: A contingent model of how the emotional regulation of anger and fear sparks proactivity. Academy of Management Review, 42(2), 190-206. https://doi.org/10.5465/amr.2014.0368

Mason, M. K. (2017). Worldwide business start-ups. Retrieved from http://www.moyak.com/papers/business-startups-entrepreneurs.html

Miles, M. B., Huberman, A. M., \& Saldana, J. (2014). Qualitative data analysis. A methods sourcebook. California: Sage.

Morrison, K. (2006). Marx, Durkheim, Weber: Formations of modern social thought. London: Sage.

Munro, R. (2017). Creativity, organisation and entrepreneurship: power and playing in the ecological press of money. Organization Studies, 39(2-3), 209-227. https://doi.org/10.1177/0170840617717550 
Oh, J. K., \& Farh, C. I. (2017). An emotional process theory of how subordinates appraise, experience, and respond to abusive supervision over time. Academy of Management Review, 42(2), 207-232. https://doi.org/10.5465/amr.2014.0347

Retolaza, J. L., San-Jose, L., \& Ruiz-Roqueñi, M. (2014). Ontological stakeholder view: an innovative proposition. Global Business Review, 15(1), 25-36. https://doi.org/10.1177/0972150913515590

Reynolds, P. D. (2005). Understanding business creation: Serendipity and scope in two decades of business creation studies. Small Business Economics, 24, 359-364. https://doi.org/10.1007/s11187-005-0692-x

Rose, D. (2012). How many start-ups in the US get seed/VC funding per year? Retrieved from http://blog.gust.com/how-manystart-ups-in-the-us-get-seedvc-funding-per-year

Rothman, N. B., \& Melwani, S. (2017). Feeling mixed, ambivalent, and in flux: The social functions of emotional complexity for leaders. Academy of Management Review, 42, 259-282. https://doi.org/10.5465/amr.2014.0355

Scarpetta, S., Sonnet, A., \& Manfredi, T. (2010). Rising youth unemployment during the crisis: How to prevent negative long-term consequences on a generation? (OECD social, employment and migration working papers, No. 106). Paris: OECD Publishing.

Spreitzer, G. M., \& Sonenshein, S. (2004). Toward the construct definition of positive deviance. American Behavioral Scientist, 47(6), 828-847. https://doi.org/10.1177/0002764203260212

Stephan, U., Hart, M., Mickiewicz, T., \& Drews, C.-C. (2015). Understanding motivations for entrepreneurship: A review of recent research evidence (BIS research paper 212, Department for Business, Innovation and Skills). Aston University. 109 p. Aston. https://doi.org/10.13140/RG.2.1.3343.2165

Stevenson, H. H., \& Jarillo, J. C. (2007). A paradigm of entrepreneurship: Entrepreneurial management. In Á. Cuervo, D. Ribeiro, \& S. Roig (Eds.), Entrepreneurship (pp. 155-170). Berlin, Heidelberg: Springer. https://doi.org/10.1007/978-3-540-48543-8_7

Tunčikienè, Ž., \& Sinkevičiūtè, G. (2017). Strenthening opportunities of economic relations between Lithuania and Sweden within the perspective of it startup company's development. Business, mana gement and education, 15(1), 57-76. https://doi.org/10.3846/bme.2017.357

Yin, R. K. (1984). Case study research and applications: Design and methods. Beverly Hills, CA: SAGE Publications.

Yin, R. K. (2001). Estudo de caso: planejamento e métodos (2 ed.). Porto Alegre: Bookman. 